\title{
REVIEW AR'TICLE
}

\section{An Update on the Cellular and Molecular Biology of Brain Tumors}

\author{
Michael D. Cusimano
}

\begin{abstract}
Patients with tumors of the central nervous system (CNS) remain difficult to treat despite recent advances in surgical, chemotherapeutic and radiotherapeutic techniques. A better understanding of the molecular and cellular biology of neoplasia is providing neuroscientists with a framework on which to devise novel therapies for these patients. It thus becomes imperative that neurologists and neurosurgeons be aware of these advances in basic science that may eventually have a positive impact on patient management. This paper reviews our present knowledge of the process of CNS oncogenesis and the roles that chemicals, viruses, oncogenes, growth inhibitor genes, and growth factors play in the process.
\end{abstract}

RÉSUMÉ: Mise à jour sur la biologie cellulaire et moléculaire des tumeurs cérébrales Les patients porteurs de tumeurs du système nerveux central (SNC) demeurent difficiles à traiter malgré les progrès récents réalisés dans le domaine de la chirurgie, de la chimiothérapie et de la radiothérapie. Une meilleure compréhension de la biologie moléculaire et cellulaire des néoplasies fournit aux chercheurs une structure logique pour élaborer de nouvelles thérapies pour ces patients. Ainsi, il devient impératif que les neurologues et les neurochirurgiens prennent connaissance de ces progrès dans le domaine des sciences fondamentales parce qu'ils peuvent éventuellement avoir un impact positif sur le traitement de ces patients. Nous revoyons dans cet article les connaissances actuelles sur le processus d'oncogénèse dans le SNC et les rôles que jouent les produits chimiques, les virus, les oncogènes, les gènes inhibant la croissance et les facteurs de croissance dans ce processus.

This paper reviews the factors regulating the growth and differentiation of brain tumors and is based on the paradigm that oncogenesis is a multistep process. ${ }^{1}$ In this model, a carcinogenic substance is thought to act on a target cell and induce biochemical change in the deoxyribonucleic acid (DNA) of the host cell. It is hypothesized that to firmly establish an inheritable change in the altered host genome the cell must undergo a round of cellular proliferation. Once "initiated", the cell evolves through a series of changes, aided by certain "promoting" agents, which eventually lead to the malignant phenotype. This evolution can be seen when an initially low grade astrocytoma is later, at reoperation or autopsy, found to be highly malignant or demonstrated within a single tumor which contains areas of different degrees of anaplasia merging inperceptibly with areas of gliosis.
I will discuss in this review how this process occurs, try to explain the role that oncogenes and their products play in the process and, finally, briefly speculate on some of the new possibilities of treatment that may result from this knowledge in cellular biology.

\section{INITIATORS}

Neoplasms of the central nervous system (CNS) account for approximately $2 \%$ of malignancies. However, up until the age of 20 , they account for $1 / 4$ of human cancers. ${ }^{2}$ The fact that cells must undergo a round of cellular proliferation prior to becoming initiated may in part explain why the developing central nervous system is so susceptible to carcinogenic influences. This susceptibility of the developing central nervous system to car-

From the Division of Neuropathology, St. Michael's Hospital, 30 Bond Street, Toronto, Ontario, Canada M5B 1W8

Received January 7, 1988. Accepted in final form August 29, 1988

Reprint requests to: Dr. M. Cusimano, Chief Resident, Division of Neurosurgery, St. Michael's Hospital, 30 Bond Street, Toronto, Ontario, Canada M5B 1W8 
cinogenic influences has been used to advantage in experimental systems studying the carcinogenic process by various substances such as viruses and chemicals. Despite the wealth of animal studies demonstrating chemical and viral carcinogenesis in the CNS, vinyl cloride has been the only substance shown to be related to human brain tumor development. ${ }^{3}$

\section{Viruses and CNS Tumors}

The role of viruses in the induction of primary intracranial tumors has been a matter of discussion for many years. Although there exists extensive circumstantial evidence ${ }^{4-12}$ and reports of the recovery of human papovavirus from an intracerebral reticulum cell sarcoma ${ }^{13}$ and glioblastoma multiforme ${ }^{14}$ and adenoviruses from a pituitary adenoma and an astrocytoma, it remains to be proven that viruses play a direct and causative role in the pathogenesis of human brain tumors. ${ }^{15}$ Despite this, the evidence for viral induction of brain tumors in laboratory animals is quite extensive. $4,5,11,15-19$

Broadly speaking, viruses can be classified into DNA or RNA viruses. The main groups of DNA viruses that have been implicated are the papovaviruses and the adenoviruses. These viruses have induced a variety of tumors ranging from ependymomas, choroid plexus, papillomas, medulloblastomas, pineocytomas, glioblastomas and undifferentiated neuroectodermal tumors in a variety of animals ranging from hamsters to monkeys. The avian, murine, and simian sarcoma viruses are retroviruses of the RNA group that have been shown to induce mainly astrocytic tumors in various rodents, dogs, and monkeys. ${ }^{5}$

Multiple theories exist on how viruses induce brain tumors but most describe an alteration of host genome expression. The retrovirus contains the enzyme, reverse transcriptase, and it is postulated that this enzyme gives the retrovirus its oncogenic potential. Once within a host cell, the reverse transcriptase is able to form a DNA copy of the viral RNA using transfer RNA as template structures. It is then able to construct a complementary strand of the viral DNA and insert this into the host genome. By doing so, the new viral DNA may now alter the expression of certain host cell genes regulating the mitogenic process and use host cell machinery to replicate its own viral proteins. This process may allow reexpression of host cell genes normally present for cell growth and differentiation (ie: "protooncogenes"). With the alteration of the normal control of such gene expression, the cell may then undergo oncogenesis. ${ }^{15}$ Another possibility is that the viral gene may itself be homologous to the normal cellular proto-oncogene, and because of its position, not be subject to the usual controls. This characteristic might allow the viral gene to be expressed continuously, leading to the malignant phenotype.

\section{Chemical Carcinogenesis}

Seligman and Shear ${ }^{20}$ were the first to demonstrate that chemical substances could induce brain tumors. They placed cyclic aromatic hydrocarbons directly within the brain and noted that a variety of brain tumors could be induced. Since then, the two main groups of chemicals which have been shown to produce neoplasia in the CNS, by either implantation or administered systemically, have been the aliphatic alkylating agents and the polycyclic hydrocarbons.

Methyl and ethyl nitrosurea and several other methylating and ethylating agents have been shown to cause brain tumors in up to $90-100 \%$ of the offspring of pregnant rats injected with such material.4,18,21 It appears as though initiation of target cells requires a covalent interaction between the carcinogen or a metabolically activated carcinogen by-product and the DNA molecule. ${ }^{4}$ For example, the $\mathrm{N}$-nitroso compounds have a high affinity for the CNS and cross the blood brain barrier easily. They have a half life of less than 10 minutes and are metabolized to alkyl cations which interact covalently with the nucleophilic groups of DNA to cause mispairing of nucleotide sequences and thus point mutation in the host genome. ${ }^{22}$ Such mutations may also be related to chromosomal deletions and duplications. These mutations may remove normal control mechanisms placed on genes regulating cell growth and differentiation and lead to malignancy. ${ }^{4}$ The diakyltrizenes and the hydrazines are both thought to act in a similar fashion. ${ }^{4}$ 18, 21

One other factor that may be functional in brain tumor chemical carcinogenesis may be an impaired ability of the damaged host cell to repair its DNA. Kleihues et al demonstrated the long term persistence of $\mathrm{O}^{6}$-methylguanine in rat brain DNA of adult female PV-1X rats given a single intravenous injection of $\mathrm{N}$ -

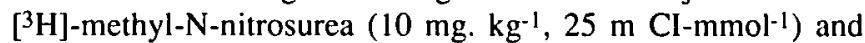
suggested that the repair capacity of neural tissue for $\mathrm{O}^{6}$. methylguanine was reduced. ${ }^{23,24}$ Such deficient DNA repair capacity may be related to CNS-specific chemical carcinogenesis.

\section{Promoters}

It has never been shown conclusively that promoters are directly involved with human carcinogenesis; however, various hormones, immunosuppressants and some viruses are thought to function as such. The most significant of these appears to be the association between secretion of messengers in the endocrine system and the link with cell proliferation. Lloyd et a ${ }^{25}$ have shown a direct correlation between the secretory activity of a prolactin cell and its proliferation. This correlation may also be seen in other hormonally regulated endocrine cells such as thyrotrophs, corticotrophs, somatotrophs, parathyroid cells and gastric parietal cells. ${ }^{26-33}$ Conversely, treatment of certain tumors such as prolactinomas with dopamine agonists which may act as "anti-promoters", suppress secretory activity, decrease tumor growth and cause tumor involution. ${ }^{34-36}$

\section{Oncogenes, Growth Factors, and Multistage. Carcinogenesis}

Chemical carcinogens do not introduce new DNA into a host cell but rather affect genes necessary for normal cell growth and differentiation (termed "proto-oncogenes"). Activated protooncogenes become "oncogenes" capable of contributing to the carcinogenic process. Two hypotheses have been proposed to explain the mechanism of activation of proto-oncogenes. The first involves a retrovirus carrying a viral-onc $(v-o n c)$ gene integrating into host DNA or the insertion of - a viral promotor and/or enhancer turning on expression of a cellular-onc (c-onc) gene. ${ }^{37-39}$ The second involves structural chromosomal abnormalities such as deletions, duplications and reciprocal translocations associated with aberrant expression of a proto-oncogene..$^{40}$ Retinoblastomas, ${ }^{41}$ neuroblastomas ${ }^{42}$ and Wilms' tumors ${ }^{43}$ have been shown to have deletions involving small portions of a 
chromosome. It appears, however, that several oncogenes work together to produce malignant transformation and that the activation of a single proto-oncogene is but a single step in the multistep process. $44-51$

\section{Signal Transduction}

Exactly how oncogenes implement the transformation of the malignant phenotype is unknown but a major theme that has emerged is that the proto-oncogenes represent a subset of genes that normally code for components in the pathways of cellular signal transduction.

A multicellular organism must be able to coordinate the behaviour of individual cells. It can do this through endocrine, paracrine or autocrine communication. In the endocrine system, a chemical messenger is secreted into the blood stream to act as a distant tissue (for eg. insulin). The paracrine system acts at neighbouring cells within a short range and the autocrine system acts at the same cell secreting the messenger. In all of these systems, once the signal has been received, a cascade of signal transduction flows through the cytoplasm and eventually into the nucleus to alter the expression of certain genes. Since protooncogenes are a set of genes that normally code for components in these pathways of signal transduction, alterations or "activation" of proto-oncogenes will cause aberrations in signal transduction and thus disrupt normal growth, differentiation and intercellular communication.

Protein kinases play a central role in these processes. Activation of protein kinases can occur in 3 ways. First, occupancy at the Beta adrenergic receptor leads to activation of adenylate cyclase and through coupling of $\mathrm{G}$ regulatory proteins, increased in cyclic AMP (CAMP) activates protein kinase $\mathrm{A}$, a serine and threonine kinase. ${ }^{52-53}$ In some cases, CAMP can induce reversion of the transformed phenotype ie. an inhibiting regulator of growth. ${ }^{54,55}$ The second method is through phospholipase via protein kinase $\mathrm{C}$ ( $\mathrm{PKC})$, also a serine and threonine kinase. ${ }^{56.57}$ Several agonists activate phospholipase C which hydrolyses phosphatidyl inositol 4,5 diphosphate to diacylglycerol (DAG) and inositol 1,4,5 triphosphate $\left(\mathrm{IP}_{3}\right)$. DAG leads to activation of $\mathrm{PKC}$, and, $\mathrm{IP}_{3}$ binds to endoplasmic reticulum to cause release of $\mathrm{Ca}^{+2.56-58}$ Calcium then activates several calmodulin-dependent enzymes (such as protein kinases, phosphatases, phosphodiesterases) and also affects the cytoskeleton. The tumor promoter 12-0-tetradecanoylphorbolB-acetate (TAP) apparently acts in place of DAG. ${ }^{55}$ The final method of protein kinase activation is via stimulation of growth factor receptors by substances such as platelet derived growth factor (PDGF), epidermal growth factor (EGF), insulin and certain lymphokines. ${ }^{52,53}$ They activate a tyrosine kinase present on the cytoplasmic portion of the receptor.

Exactly how the proteins phosphorylated by all these kinases reach the nucleus and affect genomic expression is unknown but a hypothesis is that it may occur through phosphorylation of DNA methyltransferase that methylates DNA and affects gene expression. They may also alter expression of the myc and fos oncogenes which are genes thought to be important in cell proliferation and differentiation. ${ }^{59-61}$ Alternative explanations have been through activated forms of oxygen or alteration of levels of poly-ADP-ribose..$^{52,53}$

Shapiro et a ${ }^{62}$ performed cytometric studies on freshly excised glioblastoma and found that low grade areas contained cells with chromosomal number near diploid, whereas cytologically malignant area cells were mainly tri- and tetraploid. Karyotype analysis revealed multiple chromosomal anomalies including translocations, deletions and duplications; however, over-representation of chromosome 7 and under-representation of chromosome 22 and the sex chromosome were the most common patterns. ${ }^{62}$

Three recent observations suggest how Shapiro's findings may be related to glial malignancy. The first is that the receptors of PDGF and EGF exist on normal and malignant glial cells. ${ }^{63-}$ 68 The second is that the proto-oncogene sis (c-sis) encodes for one of the polypeptides of PDGF and maps onto chromosome 22.69,70 The third is that chromosome 7 contains the c-erb-B proto-oncogene which encodes for 3 of the 4 domains of the EGF receptor. ${ }^{71,72}$ Through the truncated form of the EGF receptor (c-erb-B gene product), cell division is stimulated. Over representation of chromosome 7 is consistent with gene amplification of c-erb-B. The underrepresentation of chromosome 22 which contains the c-sis oncogene at first appears to be a paradox. However, by hypothesizing that a translocation is responsible for the apparent underrepresentation, one can postulate that normal gene product of c-sis, PDGF, has lost its normal constraints and is expressed to a higher degree. These early findings suggest that gliomas may have hyperexpression of genes associated with mitogenesis.

\section{Oncogenes and Brain Tumors}

The sis gene was first known as a viral transforming gene ( $v$ sis) of the Simian Sarcoma Virus (SSV) and later found to be closely related to the cellular sis (C-sis) gene that produced PDGF ${ }^{73,74}$ The protein encoded for by $\mathrm{v}$-sis in SSV transformed cells called p 28 is similar to PDGF and is secreted in a biologically active form capable of stimulating protein synthesis. ${ }^{73,74}$ This gene product appears to stimulate proliferation of the cell which produced it (i.e. autocrine mechanism). However, exogenously added PDGF antibodies do not completely suppress the growth of tumor cells, ${ }^{75}$ suggesting that the autocrine model in itself is insufficient to explain PDGF-related growth.

The second proto-oncogene of importance in gliomas is the c-erb-B gene encoding for 3 of the 4 domains of the EGF receptor. 40,77 It is structurally similar to the transforming protein verb-B of avian erythroblastosis virus (AEV) which is enhanced by another gene in the virus called v-erb-A. 76,77

In normal human cells, the EGF receptor is a $170 \mathrm{k}$ Dalton glycoprotein formed of an external binding domain, a transcellular domain and two cytoplasmic domains important in phosphorylation of tyrosine residues. ${ }^{76}$

Libermann et al found that glioblastomas contain amplified levels of EGF receptor kinase activity whereas meningiomas, oligodendrogliomas, grade II astrocytomas, and control autopsied brains do not. ${ }^{78,79}$ These findings led Libermann et al to suggst that EGF expression may accompany the malignant transformation of human brain cells of non-neuronal origin.

It has also been found that tumors can secrete other mitogens such as alpha and beta transforming growth factor capable of stimulating the EGF receptor. ${ }^{80}$ These findings, in combination with the recent demonstration of a 4-fold excess of a high molecular weight form of EGF in patients with malignant astrocytoma, ${ }^{81}$ suggest that growth factors may play a direct role in the malignant process. 
$\mathrm{N}$-myc oncogene expression has been demonstrated in neuroblastoma, retinoblastoma and astrocytoma. ${ }^{15,83,84}$ Proliferation of neuroblastomatous cells leads to a 20 -fold increased expression of this oncogene and differentiation of these cells lead to markedly decreased $\mathrm{N}$-myc oncogene expression. ${ }^{15,84}$

Finally, the $\mathrm{N}$-neu oncogene has also been described in neuroblastomas and is felt to act in a similar fashion to the v-erb-B oncogene in that it encodes for a tyrosine kinase. ${ }^{85}$ Thus, one can appreciate that there exist abundant data associating the aberrant expression of genes responsible for cell growth and neoplasia within the CNS.

\section{Differentiation and Growth Inhibition}

Since the normal organism is able to control growth and induce differentiation of the cells once the growth period or stimulus for growth has ceased, it seems logical that nature has developed a set of genes not only for growth but also a set to induce cells to undergo "terminal" differentiation and terminate continued proliferation. These genes have been called "growth inhibitor genes" by Weinstein..$^{52}$ One could easily postulate that activation of oncogenes or inactivation of "growth inhibitor genes" or "differentiation genes" could lead to growth and/or failure to differentiate. Such mutations would be recessive as it would be necessary to delete both alleles for tumors to occur. There is increasing evidence that such genes exist and are related to oncogenesis. ${ }^{86-90}$ For example, in Drosophila, flies homozygous for the mutation, "giant larvae" have an arrest of the development of the optic centres, eventual proliferation of ganglion cell precursors and development of neuroblastomas.91 In humans, neuroblastomas are known to spontaneously differentiate ${ }^{92}$ and this may represent a spontaneous expression of these growth inhibitor genes. Exactly how these genes work is unknown but Weinstein has suggested that it is possibly through protein phosphatases, protein kinases opposite to PKC, phospholipase inhibition, transcription or translation inhibitors of cell proliferation genes or through genes that induce differentiation. 52 The products of such genes may be lipid related rather than polypeptides since certain prostaglandins have inhibited tumor cell growth or induced differentiation. There already exist several agents that mimic the action of such genes or induce their expression. These agents include: retinoids, vitamin D derivatives, glucocorticoids, dimethylsulphoxide (DMSO), cyclic AMP, butyrate, TPA, mezerin, TGF-beta and certain interferons. $86,93,94$

Thus, there exists a set of genes which codes for the pathways that maintain a cell in cycle and a set that allow the cell to differentiate and terminate its proliferation. By altering the balance of growth-stimulating and growth-inhibiting gene expression, one may gain new venues for the treatment of brain tumors.

\section{Other Factors Involved in Carcinogenesis}

Undoubtedly, there are multiple other factors involved in the carcinogenic process. The immune responses to malignant cells play a major role here but are beyond the scope of this paper. ${ }^{95}$ Micro-environmental factors such as positional effects and polarity of a cell in relation to the rest of the developing cell mass are important controls governing cellular proliferation and differentiation. Cell to cell contact through recognition of sur- face antigens such as N-CAM, NG-CAM, and myelin associated glycoprotein, is important in the developing nervous system and is thought to play a major role in CNS development. ${ }^{96}$ Gradients of oxygen, ions and nutrients, especially calcium, and the role of calcium in regulating calmodulin dependent enzymes such as phosphatases is an area of intense interest. 97,98 The extracellular matrix undoubtedly influences cell to cell interactions necessary for the control of cell growth. ${ }^{99}$ Thus, when considering oncogenesis, one must remember that the cell does not live alone, but that the final expression of malignancy depends on interaction of the cell with its environment.

\section{A New Framework For Therapy}

This new knowledge of the molecular and cellular biology of brain tumors has provided a framework from which to develop new therapeutic modalities. One can hypothesize that initiated neoplastic cells with altered genetic controls secrete a group of growth promoting substances that induce proliferation in neighbouring cells via autocrine, paracrine and possibly endocrine mechanisms. Proliferating cells losing expression of differentiation genes might then develop the morphology of reactive or malignant cells. Phenomena such as glioma heterogeneity, mixed tumors or tumor angiogenesis might occur as a result of this tumor cell communication.

In the future, we may be using therapies based on knowledge of the cellular and molecular biology of brain tumors. By altering the balance of growth-stimulatory and growth-inhibitory gene expression one might induce differentiation in tumors. Utilization of growth factor antagonists, or agents designed to alter intracellular signal transduction, or tumor cell invasiveness might one day be therapeutic options for our patients afflicted by tumors of the central nervous system.

\section{ACKNOWLEDGEMENTS}

The author wishes to express his appreciation to Dr. J.M. Bilbao, Dr. K. Kovacs and Dr. L. Becker for their review of this manuscript and for their encouragement. Thanks also to Mrs. Maybelle Wong for her expert secretarial assiatance.

\section{REFERENCES}

1. Farber E. The multistep nature of cancer developments. Cancer Research 1984; 44: 4217-4223.

2. Shapiro WR. Brain tumors. Seminars in oncology 1986; 16(1): 1-3.

3. Althouse R, Huff $J$, Tomatis $L$, et al. An evaluation of chemicals and industrial processes associated with cancer in humans based on human and animal data. IARC monographs vol. 1-20. Cancer Research 1980; 40:1-12.

4. Kleihues P, Bigner DD. Tumors of the nervous system. In: Davison AN, Thompson RH (eds). Molecular Basis of Neuropathology. Edward Arnold Co, London 1981; 87-96.

5. Walsh JW, Zimmer SG, Perdue ML. Role of viruses in the induction of primary intracranial tumors. Neurosurgery $1982 ; 10(5)$ : 643662.

6. Farewell JR, Dohrmann GJ, Marrett LD, et al. Effect of SV40 virus-contaminated polio vaccine on the incidence and type of CNS neoplasms in children: A population-based study. Trans Am Neurol Assoc 1979; 104: 261-263.

7. Heinonen OP, Shapiro S, Monson RR, et al. Immunization during pregnancy against poliomyelitis and influenza in relation to childhood malignancy. Int J Epidermiol 1973; 2: 229-235.

8. Geissler E, Scherneck S, Waehite $\mathrm{H}$, et al. Further studies on the relationship of SV40-like viruses to human tumors. Cold Spring Harbor Conf Cell Proliferation 1980; 7: 343-356. 
9. Israel MA, Martin MA, Takemoto KK, et al. Evaluation of normal and neoplastic human tissue for BK virus. Virology 1978; 90 : 187-196.

10. Ibelgaufts $H$. Are human DNA tumor viruses involved in the pathogenesis of human neurogenic tumors? Neurosurg Rev 1982; 4: 3-24.

11. Ibelgaufts H. DNA viruses and brain tumors. TINS 1982; 5: 16-20.

12. Takenaka N, Mikoshiba K, Takamatsu K, et al. Immunohistochemical detection of the gene product of Rous sarcoma virus in human brain tumors. Brain Res 1985; 337: 201-207.

13. Takemoto KK, Rabson AS, Mullarbey MF, et al. Isolation of papovavirus from brain tumor and urine of a patient with WiskottAldrich syndrome. J Natl Cancer Inst 1974; 53: 1205-1207.

14. Scherneck S, Rudolph M, Geissler E, et al. Isolation of an SV-40 like papovavirus from a human glioblastoma. Int J Cancer 1979; 24: 523-531.

15. Schmidek $\mathrm{HH}$. The molecular genetics of nervous system tumor. J Neurosurg 1987; 67: 1-16.

16. Palmiter RD, Brinster RL. Transgenic mice. Cell 1985; 41: 343345.

17. Bigner DD, Pegram CN. Virus induced experimental brain tumors and putative associations of viruses with human brain tumors: a review. In: Thompson RA, Green JR, eds. Advances in Neurology. Raven Press, New York 1976; 15: 57-83.

18. Saris SC, Bigner DD. Experimental Neuro-oncology. In: Crockard D, Thomas BK, eds. Neurosurgery: The scientific basis of clinical medicine. St. Louis, Mosby 1985; 392-416.

19. Walker JS, Bigner DD. Virus induced brain tumors. In: Wilkins RH, Rengachary S, eds. Neurosurgery. McGraw Hill Book Co, New York 1985; 522-525.

20. Seligman AM, Shear MJ. Studies in carcinogenesis VIII. Experimental production of brain tumors in mice with methylcholanthrene. Am J Cancer 1939; 37: 364-399.

21. Lantos PL. Development of nitrosurea-induced brain tumors with special note on changes occurring during latency. Food Chem Toxicol 1986; 24(2): 121-127.

22. Hodgson RM, Weissler M, Kleihues P. Preferential methylation of target organ DNA by the esophageal carcinogen N-nitrosomethylbenzylamine. Carcinogenesis 1980; 1: 861-866.

23. Kleihues $\mathrm{P}$, Buechleler J. Long term persistence of $\mathrm{O}^{6}$-methylguanine in rat brain DNA. Nature 1977; 269: 625-626.

24. Kleihues P, Bamborschke S, Doerjes G. Persistence of alkylated DNA bases in the Mongolian gerbil (Meriones ungiuiculates) following a single dose of methylnitrosurea. Carcinogenesis 1980; 1: 111-113.

25. Lloyd HM, Meares JD, Jacob J. Effects of estrogen and bromocryptine on in vivo secretion and mitosis in prolactin cells. Nature 1975; 225: 497-498.

26. Asa SL, Kovacs K, Tindall GE, et al. Cushing's disease associated with an intrasellar gangliocytoma producing corticotropinreleasing factor. Ann Int 1984; 101: 789-793.

27. Billestrup N, Swanson LW, Vale W. Growth hormone-releasing factor stimulates proliferation of somatotrophs in vitro. Proc Natl Acad Sci, USA 1986; 83: 6854-6857.

28. Bordi C, Plato F, Cartagna G, et al. Argyophil cell hyperplasia of fundic mucosa in patients with chronic atrophic gastritis. Digestion 1986; 36: 130-143 (Suppl 1).

29. Borch K, Renvall H, Leedberg G. Gastric endocrine cell hyperplasia with carcinoid tumors in pernicious anemia. Gastroenterology 1985; 88: 638-648.

30. Carey RM, Varma SK, Drake CR Jr, et al. Ectopic secretion of corticotrophin-releasing factor as a cause of Cushing's syndrome: a clinical, morphological and biochemical study. $\mathrm{N}$ Engl $\mathrm{J}$ Med 1984; 311: 13-20.

31. Kovacs K, Horvath E, Ilse G. Ultrastructure of the human thyrotroph in TSH excess. Proc XI Int Cong on Electron Microscopy. Kyoto 1986; 3025-3026.

32. Nelson DH, Meakin JW, Thorn GW. ACTH-producing pituitary tumors following adrenalectomy for Cushing's syndrome. Ann Intern Med 1960; 52: 560-569.

33. Pawlikowski $M$. The link between secretion and mitosis in the endocrine glands. Life Sciences 1982; 30: 315-320.
34. Chiodini DG, Liuzzi A, Verde G, et al. Size reduction of a prolactin secreting adenoma during long-term treatment with dopamine agonist lisuride. Clin Endocrinol 1980; 12: 47-51.

35. McGregor AM, Scanlon MF, Hall R, et al. Effects of bromocryptine on pituitary tumor size. Br Med J 1979; 2: 700-703.

36. Kovacs K, Horvath E. Tumors of the pituitary gland. Atlas of Tumor Pathology Fascicle 21. Armed Forces Institute of Pathology, Washington, DC 1986; 107-108.

37. Land H, Parada LF, Weinberg RA. Cellular oncogenes and multistep carcinogenesis. Science 1983; 298: 343-347.

38. Payne GS, Bishop JM, Varmus HE. Multiple arrangements of viral DNA and an activated host onçogene in bursal lymphomas. Nature 1982; 295: 209-214.

39. Der CJ. Cellular oncogenes and human carcinogenesis. Clin Chem 1987; 33(5): 641-646.

40. Gilbert F. Chromosomes, genes and cancer: A classification of chromosome abnormalities in cancer. J Natl Cancer Inst 1983; 71: 107-114.

41. Balaban G, Gilben F, Nichols W, et al. Abnormalities of chromosome 13 in retinoblastomas from individuals with normal consitutional karyotypes. Cancer Genet Cytogenet 1982; 6: 213-221.

42. Gilbert F, Feder M, Balaban G, et al. Human neuroblastomas and abnormalities of chromosomes 1 and 17. Cancer Res 1984; 44: 5444-5449.

43. Riccardi VM, Sujansky E, Smith AC, et al. Chromosomal imbalance in Aniridia-Welm's tumor association. Pediatrics 1978; 61: 604-610

44. Murray MJ, Cunningham JM, Parada LF, et al. The HL-60 transforming sequence: A ras oncogene coexisting with altered myc genes in hematopoietic tumors. Cell 1983; 33: 749-757.

45. Assoian RK, Grotendorst GR, Miller DM. Cellular transformation by coordinated action of three peptide growth factors from human platelets. Nature $1984 ; 309: 804-806$.

46. Cooper GM, Neiman PE. Two distinct candidate transforming genes of lymphoid leukosis virus-induced neoplasms. Nature 1981; 292: 857-858.

47. Land H, Parada LF, Weinberg RA. Tumorigenic conversion of primary embryo fibroblasts requires at least two cooperating oncogenes. Nature 1983; 304: 596-602.

48. Eliyahu D, Raz A, Gruss P, et al. Participation of p53 cellular tumor antigen in transformation of normal embryonic cells. Nature 1984; 312: 646-649.

49. Parada LF, Land $\mathrm{H}$, Weinberg RA, et al. Cooperation between gene encoding p53 tumor antigen and ras in cellular transformation. Nature $1984 ; 312$ : 649-651.

50. Jenkins JR. Rudge K, Currie GA. Cellular immortalization by a cDNA clone encoding the transformation-associated phosphoprotein p53. Nature 1984; 312: 651-654.

51. Ruley HE. Adenovirus early region $1 \mathrm{~A}$ enables viral and cellular transforming genes to transform primary cells in culture. Nature 1983; 304: 602-606.

52. Weinstein IB. Growth factors, oncogenes and multistage carcinogenesis. J Cell Biochem 1987; 33: 213-224.

53. Westermark B, Nister M, Heldin $\mathrm{CH}$. Growth factors and oncogenes in human malignant glioma. Neurologic Clin 1985; 3(4): 785-799.

54. Ashall F, Puck TT. Cytoskeletal involvement in CAMP-induced sensitization of chromatin to nuclease digestion in transformed Chineere hamster ovary K1 cells. Proc Natl Acad Sci USA 1984; 81: 5145-5149.

55. Sisskin E, Weinstein IB. Isolation and characterization of a morphologic variant of Chineese hamster $(\mathrm{CHO})$ cells. J Cell Physiol 1980; 102(2): 141-153.

56. Niskizuka Y. Perspectives on the role of protein kinase $\mathrm{C}$ in stimulus-response coupling. J Natl Cancer Inst 1986; 76: 363-370.

57. Nishizuka $Y$. The role of protein kinase $C$ in cell surface signal transduction and tumor promotion. Nature 1984; 308: 693-698.

58. Berridge MJ, Irvine RF. Inositol Triphosphate. A novel second Messenger in Signal Transduction. Nature 1984; 312: 315-321.

59. Kelly K, Cochran BH, Stiles CD, et al. Cell specific regulation of the c-myc gene by lymphocyte mitogens and platelet-derived growth factor. Cell 1983; 35: 603-610. 
60. Kruijer W, Cooper JA, Hunter T, et al. Platelet derived growth factor induced rapid but transient expression of the c-fos gene and protein. Nature 1984; 312: 711-716.

61. Muller R, Bravo R, Burckhardt J. Induction of c-fos gene and protein by growth factors precedes activation of $c$-myc. Nature 1984; 312: 716-720.

62. Shapiro JR, Pu PY, Mohamed AN, et al. Regional heterogeneity in high grade gliomas. Proc Amer Assn Cancer Res 1984; 25: 375382.

63. Heldin C-H, Westermark B, Wasteson A. Specific receptors for platelet-derived growth factor on cells derived from connective tissue and glia. Proc Natl Acad Sci USA 1981; 78: 3664-3668.

64. Simpson DL, Morrison R, de Vellis J, et al. Epidermal growth factor binding and mitogenic activity on purified populations of cells from the central nervous system. J Neurosci Res 1962; 8: 453-462.

65. Heldin C-H, Westermark B, Wasteson A. Chemical and biological properties of growth factor from human-cultured osteosarcoma cells: Resemblance with platelet-derived growth factor. $J$ Cell Physiol 1980; 105: 235-246.

66. Graves DT, Owen AJ, Antoniades HN. Evidence that a human osteosarcoma cell line which secretes a mitogen similar to platelet-derived growth factor requires growth factors present in platelet-poor plasma. Cancer Res 1983; 43: 83-87.

67. Betsholtz C, Heldin C-H, Nister M, et al. Synthesis of a PDGF-like growth factor in human glioma and sarcoma cells suggests the expression of the cellular homologue to the transforming protein of simian sarcoma virus. Biochem Biophys Res Commun 1983; 117: 176-182.

68. Nister M, Heldin C-H, Wasteson A, et al. A platelet-derived growth factor analog produced by a human clonal glioma cell line. Ann NY Acad Sci 1982; 397: 25-33.

69. Dalla-Favera RC, Gallo RC, Giallongo A, et al. Chromosomal localization of the human homolog (c-sis) of the simian sarcoma virus onc gene. Science 1982; 218: 686-688.

70. Swan DC, McBride OW, Robbins KC, et al. Chromosomal mapping of the simian sarcoma virus onc gene analogue in human cells. Proc Natl Acad Sci USA 1982; 79: 4691-4695.

71. Davies RL, Grosse VA, Kucherlapati R, et al. Genetic analysis of epidermal growth factor action: Assignment of human epidermal growth factor receptor gene to chromosome 7. Proc Natl Acad Sci USA 1980; 77: 4188-4192.

72. Shimizu N, Kondo I, Gamou S, et al. Genetic analysis of hyperproduction of epidermal growth factor receptors in human epidermoid carcinoma A431 cells. Somatic Cell Mol Genet 1984; 10: $45-53$

73. Waterfield MD, Scrace GT, Whittle N, et al. Platelet-derived growth factor is structurally related to the putative transforming protein p28 sis of simian sarcoma virus. Nature 1983; 304: 3539.

74. Robbins KC, Antoniades HN, Sushilkumar G, et al. Structural and immunological similarities between simian sarcoma virus gene product(s) and human platelet-derived growth factor. Nature 1983; 305: 605-608.

75. Betsholtz C, Westermark B, Ek B, et al. Coexpression of a PDGFlike growth factor and PDGF receptors in a human osteosarcoma cell line. Implications for autocrine receptor activation. Cell 1984; 39: 447-457.

76. Hunter $T$. The epidermal growth factor receptor gene and its product. Nature 1984; 307: 521-527.

77. Downward J, Yarden Y, Mayes E, et al. Close similarity of epidermal growth factor receptor and $v$-erb-B oncogene protein sequences. Nature 1984; 307: 521-527.
78. Libermann TA. Razon N, Bartal AD, et al. Expression of epidermal growth factor receptors in human brain tumors. Cancer Res 1984; 44: 753-760.

79. Libermann TA. Nusbaum HR, Razon N, et al. Amplification, enhanced expression and possible rearrangement of the EGF receptor gene in primary human brain tumors of glial origin. Nature 1984; 313: 144-147.

80. Todaro GT, Marquardt H, Twardzik DR, et al. Transforming growth factors produced by tumor cells. In: Owens AH, Coffey DS, Baylin SB, eds: Tumor Cell Heterogeneity: Origin and Implications. Orlando, Fla, Academic 1982; 205-224

81. Stromberg K, Hudgins WR, Dormann LS, et al. Human brain tumor-associated urinary high molecular weight transforming growth factor: A high molecular weight form of epidermal growth factor. Cancer Res 1987; 47: 1190-1196.

82. Schwab M, Alitalo K, Klempnauer K-H, et al. Amplified DNA with limited homology to myc cellular oncogene is shared by human neuroblastoma cell lines and a neuroblastoma tumor. Nature (London) 1983; 305: 245-248.

83. Kohl NE, Kanda N, Schreck RR, et al. Transposition and amplification of oncogene-related sequences in human neuroblastomas. Cell 1983; 35: 359-367.

84. Seeger RC, Brodeur GM, Sather H, et al. Association of multiple copies of the $\mathrm{N}$-myc oncogene with rapid progression of neuroblastomas. N Engl J Med 1985; 313: 1111-1116.

85. Schecter AL, Hung MC, Vaidyanathan $L$, et al. The neu gene: an erb-B-homologous gene distinct from and unlinked to the gene encoding the EGF receptor. Science 1985; 229: 976-978.

86. Sachs L. Growth, differentiation and the reversal of malignancy. Sci Am 1986; 354(1): 40-47.

87. Cavenee WK, Hansen MF, Norderskjold M, et al. Science 1985; 228: 501-503.

88. Koufos A, Hansen MF, Lamphin BC, et al. Loss of alleles at loci on human chromosome 11 during genesis of Wilms' tumor. Nature 1984: 309: 170-172.

89. Green AR, Wyke JA. Anti-oncogenes. A subset of regulatory genes involved in carcinogenesis? Lancet 1985; 2: 475-477.

90. Sager R. Genetic suppression of tumor formation: A new frontier in cancer research. Cancer Res 1986; 46: 1573-1580.

91. Gateff E. Cancer, genes, and development: the Drosophila case. Adv Cancer Res 1982; 37: 33-74.

92. Rubinstein LJ. Tumors of the Central Nervous System. Second Series Fascicle 6. Armed Forces Institute of Pathology 1985; 154-157.

93. Freshney RI. Induction of differentiation in neoplastic cells Anticancer Res 1985; 5: 111-130.

94. Seeger RC. Neuroblastoma: Clinical perspectives, monoclonal antibodies, and retinoic acid. Ann Int Med 1982; 97: 873-884.

95. Bast RC, Principles of Cancer Biology: Tumor Immunology. In: DeVita VT, Hellman S, Rosenberg S, eds. Cancer Principles and Practice of Oncology. JB Lipincott Co, Philadelphia 1986; 1(2): 125-150.

96. Bunge RP, Waksman $\mathrm{BH}$. Glial development and interactions. TINS 1985; 8: 424-427.

97. Suzuki N, Kanno T, Nagata Y, et al. Inhibition of proliferative growth in glioma cells by calmodulin antagonists. J Neurosurg 1986; 65: 74-79.

98. Whitfield JF, Boynton JP, Mac Manus RH, et al. The roles of calcium and cyclic AMP in cell proliferation. Ann NY Acad Sci 1980; 339: 216-240.

99. Rutka JT. Effects of extracellular matrix proteins on the growth and differentiation of an anaplastic glioma cell line. Can J Neurol Sci $1986 ; 13: 301-306$ 